\title{
Małgorzata Korczyńska-Derkacz
}

Uniwersytet Wrocławski

\section{Rola Jana Muszkowskiego w ksztattowaniu polskiego ksiegarstwa w okresie międzywojennym}

W artykule podjęłam próbę przybliżenia zainteresowań Jana Muszkowskiego księgarstwem, którym zajmował się teoretycznie - w ramach nauki o książce - i praktycznie, współpracując ze środowiskiem księgarzy. Skupiłam się zwłaszcza na jego dążeniu do nadania działalności praktycznej odpowiedniej rangi i uczynienia księgarstwa przedmiotem refleksji teoretycznej.

\section{Księgarstwo jako nauka w ujęciu Jana Muszkowskiego}

$\mathrm{Na}$ uroczystej inauguracji Studium Księgarskiego i Kursów Księgarskich w 1928 r. Jan Muszkowski wygłosił wykład inauguracyjny na temat zadań historii polskiego księgarstwa ${ }^{1}$. Podkreślał w nim, że pierwszym etapem kształtowania się każdej dyscypliny są umiejętności praktyczne, które udoskonalane i rozwijane w pewnym momencie „stykają” się z wynikami nauki, co daje początek ich wzajemnemu przenikaniu się. Jest to w konsekwencji - mówił - „nadzwyczajnie doniosłe i płodne” dla obydwu stron². Tak właśnie dzieje się w zakresie wytwarzania i obiegu książki: „Gdy zaczyna się krystalizować i ustalać metoda badań, jesteśmy już u progu poznania naukowego w ścisłym znaczeniu tego wyrazu” - stwierdzał. „Bo wszak o charakterze naukowym badania w pewnym kierunku, lub w ogóle działalności umysłowej, decyduje nie przedmiot, a sposób [podkreśl. J.M.] badania czy rozumowania. Jeżeli zatem

${ }^{1}$ Uroczysta inauguracja Studium Księgarskiego i Kursów Ksieggarskich. „Przegląd Księgarski” 1928, R. 14 , nr 50, s. 858.

2 Tamże. 
uda się nam opracować metodą naukową pewną sumę doświadczeń działalności praktycznej, ułożyć wyniki w jednolity, konsekwentny system, postawić szereg zagadnień i otworzyć tym sposobem drogę do dalszych badań - mamy chyba prawo mówić o powstaniu nowej gałęzi wiedzy. Tak mniej więcej odbywa się proces przenikania [...] i następuje chwila, kiedy umiejętność praktyczna, rosnąc na sile i upowszechnieniu, rozszerzając zakres swej części uogólniającej, teoretycznej, porządkując materiał, zdobywając metodę - zaczyna aspirować coraz śmielej do godności dyscypliny naukowej"3. Muszkowski podkreślał, że metodyczne badania nad księgarstwem współczesnym nie były w Polsce prowadzone. Nauki księgoznawcze - zdaniem autora - nie zostały zdefiniowane, zarówno w odniesieniu do przedmiotu, jak i zakresu oraz metod badawczych. W jego opinii księgoznawstwo nie jest nauką jednolitą „[...] Stanowi raczej luźny zbiór wyników różnorodnych gałęzi poznania i działalności praktycznej, których jedyną więzią jest tylko przedmiot [podkreśl. J. M.] badania, a to, [...] nie wystarcza. [...]. Natomiast poszczególne działy wiedzy o książce nabierają zwolna, ale coraz pewniej charakteru naukowego w znaczeniu współczesnym"4 .

Historia księgarstwa i książki, to według Muszkowskiego historia różnych zawodów, idei, rozwoju ruchu umysłowego, stosunku klas społecznych do książki i do ludzi książki, dzięki której dostrzec można potrzeby duchowe, gusty i zamiłowania. Do względnie dobrze rozwiniętych i zbadanych działów księgarstwa, zaliczał początki drukarstwa oraz dzieje książki w pewnych środowiskach; jednak poza tym „do dokonania jest niemal wszystko, ażeby można

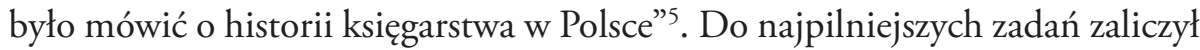
zatem opracowanie wszelkiego rodzaju dokumentów rękopiśmiennych i publikacje źródeł w szerokim rozumieniu tego terminu: od wydawnictw m.in. Jana Ptaśnika czy Teodora Wierzbowskiego, poprzez pamiętniki, korespondencje, artykuły, wzmianki w dziełach różnej treści, po same książki stanowiące źródło do bezpośrednich badań nad oprawą, ilustracją, nakładem, ceną itp. ${ }^{6}$.

W opracowanym przez siebie haśle Księgarstwo, zamieszczonym w Encyklopedii nauk politycznych w 1938 r., Muszkowski pisał: „Ponieważ towarem jest [...] książka, nosicielka treści duchowych wyrażonych za pomocą pisma lub druku - zagadnienia $\mathrm{k}$ [sięgarstwa] stają się [...] przedmiotem badań nauki o książce (bibliologii); z drugiej [...] strony k[sięgarstwo] jako zawodowe rozpowszechnianie słowa drukowanego styka się z pewnymi formami pracy kulturalno-oświatowej. [...] Księgarstwo jest jedną z gałęzi działalności prze-

\footnotetext{
3 Tamże.

4 Tamże.

5 Tamże.

${ }^{6}$ Tamże, s. 862.
} 
mysłowo-handlowej, poświęconą produkcji i rozprzedaży książek (drukowanych lub rękopiśmiennych), czasopism, rycin, map, nut - słowem, wytworów ducha ludzkiego zmaterializowanych za pomocą środków graficznych"7. Rozumiejąc potrzebę zorganizowania warsztatu pracy naukowej nad zagadnieniami księgarstwa, Muszkowski widział jednocześnie konieczność pilnego szkolenia praktyków. Uważał to za sprawę oczywistą, choć niezwykle trudną do zrealizowania. Zwracał uwagę na to, że za granicą księgarstwo było już przedmiotem studiów akademickich, np. w 1925 r., w Wyższej Szkole Handlowej w Lipsku, obok szkoły księgarskiej utworzono specjalną katedrę "nauki o handlu księgarskim" (Buchhandelsbetriebslehre) wraz z seminarium ${ }^{8}$. Przedmiot ten stanowił jedną z gałęzi specjalnych ogólnej nauki o handlu i obejmował: rodzaje, zadania i organizację placówek handlu księgarskiego; rachunkowość księgarską, konsekwencje handlowe prawa autorskiego i wydawniczego; stanowisko księgarstwa w stosunku do przemysłu graficznego i papierniczego; naukę o środkach komunikacji w księgarstwie; organizacje zawodowe księgarskie; warunki rynku dla przedmiotów handlu księgarskiego. Wykład ten stanowił wstęp do podejmowania badań naukowych na seminarium. Dawał też pogląd na to, jaki zakres problemów obejmowało księgarstwo.

Tymczasem w Polsce - jak zauważał Muszkowski - przed organizatorami przyszłej szkoły księgarskiej stanął dylemat, co ma powstać wcześniej: nauka czy uczniowie, którzy będą ją przyswajać? Na szczęście zrozumiano, że „księgarstwo nie mogło dłużej istnieć bez zdobycia podstaw teoretycznych, bez stworzenia nauki księgarstwa polskiego, [podkreśl. J.M.] zarówno na użytek praktyków-zawodowców, jak przede wszystkim - narastających pokoleń młodych księgarzy" . Badania nad kształtującą się nauką o księgarstwie, na wzór szkoły lipskiej, można by było prowadzić w ramach seminarium przy planowanym Studium Księgarskim.

\section{Studium Księgarskie i Kursy Księgarskie}

Powołany do życia w 1908 r. Związek Księgarzy Polskich (ZKP), dziesięć lat później, w wolnej Polsce, stanął wobec trudnych zadań organizacyjnych. Problemem było rozdrobnione księgarstwo nakładowe i sortymentowe, przypadkowość osób wchodzących do zawodu, brak wykształcenia ogólnego i fachowego. Powstające po latach niewoli urzędy, szkoły, warsztaty pracy naukowej,

7 J. Muszkowski, Ksiegarstwo, w: Encyklopedia nauk politycznych. T.3, z. 3, Warszawa 1938, s. 458.

${ }^{8}$ [J.M.], Zagadnienie kryzysu książki. Księgarstwo jako nauka. „Przegląd Księgarski” 1930, R. 16, nr 3, s. 37-38.

9 J. Muszkowski, Po roku. „Przegląd Księgarski” 1930, R. 16, nr 25, s. 341. 
biblioteki, podjęta przez państwo walka z analfabetyzmem, dążenie do rozwoju czytelnictwa i wzrostu produkcji książkowej zmuszały także do zmiany samego zawodu księgarza, tym bardziej, że ocena tego zawodu była dość surowa. Jak pisał w 1918 r. Aleksander Heflich - ówczesny redaktor „Przeglądu Księgarskiego” - składa się ono „[księgarstwo prowincjonalne] w dużej mierze z księgarzy przygodnych, [...] Są między nimi tacy [...], którzy ani czytać, ani pisać po polsku nie umieją [...]"10. Dotychczasowy księgarz-praktyk, samouk, stanął więc wobec nowych i trudnych zadań, do opanowania których potrzebna była wiedza, inne metody i sposoby działania.

Jubileusz dziesięciolecia I Zjazdu ZKP'11 w 1928 r. sprowokował Muszkowskiego do podsumowania tego okresu na łamach „Przeglądu Księgarskiego”, gdzie pytał: „Czy księgarstwo stało się istotnie potęgą w życiu kulturalnym państwa? Czy książka, odarta z dawnej aureoli jedynego przejawu żywotności narodu zdobyła sobie stanowisko przedmiotu niezbędnej potrzeby, tuż obok chleba i odzieży?” ${ }^{12}$. Odpowiedź była negatywna, bo księgarstwo - w jego opinii - nie stało się potęgą, którą stać się miało. „Może - pisał - tkwi jeszcze zanadto $\mathrm{w}$ dawnych przedwojennych przyzwyczajeniach kramarskich, może brak mu gestu wielkiego przemysłu"13. Rozwiązania problemu szukał w specjalizacji, celowym podziale pracy, podniesieniu poziomu wykształcenia pracowników księgarskich, lepszej organizacji pracy, popularyzacji, w podkreślaniu roli książki w funkcjonowaniu młodego państwa i całym społeczeństwie.

„Najzdolniejsze tylko, najlepiej przygotowane do życia i do zawodu jednostki zdołały się utrzymać na powierzchni, inni zapadli w bezwład, spoglądając przerażonymi oczyma na wielkie, niezwykłe wydarzenia, do których nie dorośli, poprzestając na biernej, powierzchownej krytyce wszystkiego i wszystkich, lub na lamentach i wyrzekaniach" - pisał na łamach tegoż pisma Muszkowski ${ }^{14}$. Pogląd na temat słabego przygotowania księgarzy do pracy i ich ogólnie słabego wykształcenia pobrzmiewał także w wypowiedziach Jana Piątka ${ }^{15}$, działacza ZKP. Uważał on, że brakuje im umiejętności pracy umysłowej, są mało oczytani, nie znają zasad naukowej organizacji pracy, tak szeroko rozwijanej już wówczas na zachodzie Europy, a wśród bibliotekarzy popularyzowanej przez Adama Łysakowskiego.

\footnotetext{
${ }^{10}$ Cyt. za B. Klukowski, Księgarstwo i zawód księgarza w Polsce. Warszawa 2008, s. 56-57.

${ }_{11}$ Pierwszy Zjazd ZKP miał miejsce w sierpniu 1918 r. w Lublinie. Sprawozdanie komitetu organizacyjnego i relacje z przebiegu obrad zamieścił „Przegląd Księgarski” w nr 1 z 1918 r.

12 J. Muszkowski, Po dziesięciu latach. „Przegląd Księgarski” 1928, R. 14, nr 49, s. 779.

13 Tamże, s. 781.

${ }_{14}$ Tenże, Po roku. Tamże, 1930, R. 16, nr 25, s. 341.

15 J. Piątek, Oczytanie pracowników księgarskich. Tamże, nr 17, s. 234.
} 
Jan Muszkowski sprawą szkolenia księgarzy zajmował się już od 1916 r., kiedy to uzyskawszy aprobatę Kasy Przezorności i Pomocy Warszawskich Pomocników Księgarskich, wraz z Mieczysławem Rulikowskim zorganizował w ramach Towarzystwa Kursów Naukowych, roczne kursy pracowników księgarskich. Kursy te ukończyło trzech z dwudziestu rozpoczynających je księgarzy. Powrócił do tej problematyki w referacie wygłoszonym na Walnym Zgromadzeniu ZKP 20 września 1927 r. ${ }^{16}$. Twierdził, że projekty zmierzające do poprawy sytuacji w księgarstwie polskim po 1918 r., odnoszące się do warunków wytwarzania i obiegu książki oraz konsolidacji księgarstwa, są przyjmowane entuzjastycznie, ale szybko zapominane. $Z$ dużą ostrożnością radził więc podchodzić do projektów założenia w Warszawie szkoły księgarskiej i kursów dokształcających. Projekt taki, przy życzliwym poparciu całego środowiska, musiałby być „dziełem i własnością całego księgarstwa, nie tylko [myślą] przez nie stworzoną, lecz podlegającą stale jego kontroli i kierunkowi [...] nie wolno stanowi księgarskiemu zachować bierności, ani polegać na inicjatywie i działalności organów reprezentujących i wykonawczych organizacji zawodowej”17. A oczekiwania środowiska były znaczne. Prezes ZKP, Gustaw Kazimierz Wolff o mającej powstać szkole, mówił z nadzieją: „Organizująca się Szkoła Księgarska ma duże zadanie do spełnienia. Winna ona postawić należycie sprawę wykształcenia fachowego i w tym charakterze winna doznać poparcia całego księgarstwa. [...] będzie ona miała oprócz działania bezpośredniego również i pośrednie, bowiem oprócz słuchaczów wychowa także i wykładających, jak również zbierze materiał teoretyczny, który i poza szkołą może być następnie w różny sposób wykorzystany"18.

Sprawami organizacyjno-administracyjnymi i finansowymi, związanymi z powołaniem szkoły księgarskiej, doborem wykładowców i rekrutacją słuchaczy zajęto się na plenarnym posiedzeniu Zarządu Głównego ZKP, które odbyło się w Warszawie 2 grudnia 1927 r. Podczas spotkania przedstawiono wstępny projekt programu studium księgarskiego i kursów, zawierający wykaz przedmiotów i liczbę godzin. Miał on być następnie uzupełniany i doskonalony po konsultacjach z prowadzącymi zajęcia tak, by odzwierciedlał rzeczywiste potrzeby praktyki księgarskiej. Równie wstępnie został nakreślony budżet roczny szkoły i kursów oraz plan pokrycia kosztów, który zakładał pozyskanie środków nie tylko od słuchaczy, ale przede wszystkim od firm księgarskich kierujących na kursy swoich współpracowników. Poważny problem pozyskania lokalu

16 J. Muszkowski, O wyksztatcenie zawodowe ksiegarskie. Referat wygtoszony na Walnym Zgromadzeniu ZKP w dn. 20 XI 1927. Tamże 1927, R. 13, nr 26, s. 527-532.

17 Tenże, Szkota Księgarska powstaje!'Tamże 1928, R. 14, nr 3, s. 36.

18 Z życia organizacyjnego. II posiedzenie plenarne Zarządu Gtównego Z.K.P. Tamże, nr 10, s. 157-158. 
miał szanse być rozwiązany dzięki współpracy nawiązanej z Wolną Wszechnicą Polską (WWP) i obietnicą włączenia szkoły w jej struktury. Studium Księgarskie usytuowane na Wydziale Pedagogicznym, miało więc być szkołą księgarską na poziomie wyższym, wymagającą od kandydatów matury. Kursy Księgarskie natomiast miały mieć charakter dokształcający, a warunkiem przyjęcia na nie byłoby zaświadczenie o praktyce księgarskiej. Struktura organizacyjna szkoły, choć rozdzielona pod względem formalnym, byłaby spójna dzięki osobom wykładowców i wspólnemu kierownikowi Studium i Kursów, na które to stanowisko powołano Muszkowskiego. Kuratorem mianowano dr. Jana Piątka. O sprawach szkoły decydować miał Komitet w składzie: prof. Helena Radlińska (dziekan Wydziału Pedagogicznego WWP - przewodnicząca), dr Jan Piątek, przedstawiciel ZKP (sekretarz), senator Stanisław Boguszewski, jako przedstawiciel Zarządu WWP, dyrektor Biblioteki Publicznej m.st. Warszawy, Faustyn Czerwijowski, jako przedstawiciel grupy bibliotekarskiej w Studium Pracy Społeczno-Oświatowej i prof. Jan Muszkowski jako kierownik szkoły. Porozumienie między Zarządem ZKP a władzami Wolnej Wszechnicy zostało zawarte z początkiem 1928 r., a uroczysta inauguracja miała miejsce 29 listopada tegoż roku. Wykład inauguracyjny pt. „Zadania historii księgarstwa polskiego" wygłosił Jan Muszkowski ${ }^{19}$.

Przystępując do opracowania programu przyszłej szkoły zawodowej, Jan Muszkowski ubolewał, że niewiele wiadomo na temat jej potencjalnych uczniów. Pytał na łamach „Przeglądu Księgarskiego”: „Jacy jesteście? Czego oczekujecie od szkoły? Ilu Was jest?"20. Podkreślał, że to wiedza najważniejsza dla organizatorów, bowiem: „Jesteśmy [...] w tym położeniu, że nie wiemy absolutnie nic, nie tylko o poziomie, zainteresowaniach, dążeniach i potrzebach pracowników i praktykantów księgarskich, lecz nawet o ich liczebności. Organizatorzy szkoły pragnęliby uniknąć jak najzupełniej teoretyzowania, wznoszenia budowli na nieznanych, niezbadanych, a przeto kruchych może podstawach, dążą zaś do tego, by każdy słuchacz szkoły czuł się w niej, jak u siebie, uważał ją za instytucję własną, wyrosłą w celu zaspokojenia jego potrzeb i tęsknot, stanowiącą narzędzie do rozszerzania zakresu i możności działania w praktyce zawodowej [...]”21. Uważał, że księgarz powinien być człowiekiem należycie wykształconym w sensie ogólnym, znającym dobrze literaturę współczesną, jej główne kierunki i przedstawicieli. Helena Radlińska, wspiera-

19 Uroczysta inauguracja..., s. 855-863.

20 J. Muszkowski, Szkota Księgarska..., s. 37.

${ }^{21}$ Tamże. Jak czytamy w Sprawozdaniu z pierwszego dwulecia kursów księgarskich ankieta rozesłana do księgarń wiosną 1928 r. w celu uzyskania odpowiedzi na nurtujące Muszkowskiego pytania, zawiodła. Por. tamże 1930, R. 16, nr 12, s. 174-180. 
jąca go w staraniach założenia szkoły dodawała, iż zawód wydawcy i księgarza różni się od innych zawodów, gdyż to właśnie oni, współpracując z autorem i czytelnikiem, decydują często o obiegu książki - narzędziu kultury²2.

Opracowany przez Muszkowskiego program dwuletniej szkoły księgarskiej był programem oryginalnym - szkoły księgarskie istniejące w Lipsku i w Paryżu działały w zupełnie odmiennych, od polskich, warunkach. Założeniem podstawowym było połączenie celu praktycznego, jakim było kształcenie pomocników księgarskich, ze stworzeniem podstaw teoretycznych dla rozwijającej się dyscypliny.

Naukę w Studium Muszkowski planował na dwa lata obejmujące łącznie około 320 godz. Blisko 57\% (182 godz.) całości stanowiły przedmioty księgarskie: historia księgarstwa, przemysłu wydawniczego i samej książki, jej obiegu i czytelnictwa, księgarstwo sortymentowe, rachunkowość, korespondencja i prawo handlowe w zastosowaniu do księgarstwa oraz ćwiczenia w „korzystaniu z książek", co oznaczało zapewne poznanie zasad analizy treściowej i formalnej książki. Przyjęto założenie, że osoby studiujące na wydziałach WWP słabo lub wcale nie są zorientowane w takich zagadnieniach, jak księgoznawstwo, bibliografia, bibliotekoznawstwo, a o naukach związanych z handlem nie mają być może żadnej wiedzy. Biorąc to pod uwagę uznano, że młodzieży tej wyższy poziom przygotowania ogólnego nie będzie przeszkadzał w korzystaniu z wykładów specjalistycznych przeznaczonych dla praktykantów księgarskich, mających prawdopodobnie większą nieco wiedzę specjalistyczną, ale reprezentujących niższy poziom wiedzy ogólnej. Pozostawiono słuchaczom swobodę w wyborze przedmiotów z innych wydziałów Wolnej Wszechnicy Polskiej, wymagając jednocześnie uczestnictwa w specjalistycznych wykładach, przeznaczonych dla słuchaczy Kursów Księgarskich. Zakładano, że grupa przedmiotów ściśle księgarskich, wykładana na Studium, będzie równocześnie dostępna dla słuchaczy Kursów Księgarskich. Dwuletnie wykłady, obok fachowego kursu księgarskiego, objąć miały także przedmioty z programu kształcenia bibliotekarzy i z innych wydziałów WWP. Na pograniczu przedmiotów o charakterze ogólnym i przedmiotów specjalistycznych, znalazł się przedmiot określony jako „nauka wymowy”, na który poświęcono 13 godz. Dotyczył on ćwiczeń w zakresie poprawnej wymowy, estetyki żywego słowa, „wymowy handlowej”, czyli prawdopodobnie umiejętności prowadzenia pertraktacji handlowych oraz rozmów z klientami. $\mathrm{Na}$ zaznajomienie studiujących z polską literaturą współczesną i jej stosunkiem do historii literatury z punktu widzenia potrzeb handlu księgarskiego, przeznaczono 65 godz. (ok. 20\%). Przedmioty związane

22 Uroczysta inauguracja..., s. 855. 
z poznaniem języka polskiego, zwłaszcza rodzajów literackich, stylu literackiego i naukowego, zająć miały 20 godz., co dawało ok. 6\% całości. Nieco ponad 8\% (26 godz.) przeznaczono na przedmioty związane z poznaniem kraju: zasad prawno-politycznych, warunków geograficznych i przyrodniczych, ludności, historii, przemysłu i handlu, kultury i sztuki, nauki i jej organizacji oraz prasy ${ }^{23}$. Dalsza rozbudowa programu i stworzenie specjalnego seminarium z bibliografii i historii księgarstwa miałyby na celu pogłębienie podstaw pracy naukowej słuchaczy Studium. Dodatkowo uczestnicy kursów mieli się uczyć języka niemieckiego.

Analiza przedstawionego programu świadczy o tym, że zamiarem było przygotowanie pracowników księgarskich stopnia wyższego - kierowniczego i pracowników pomocniczych, księgarzy - handlowców, mających bezpośredni kontakt z klientem. Od pierwszych kandydatów, dla których przygotowany był program Studium Księgarskiego, już na wstępie wymagano więcej: dwóch lat praktyki, matury, dwóch lat studiów wyższych na dowolnym kierunku. Ukończenie nauki w Studium miało poszerzyć i ugruntować ich wiedzę specjalistyczną; absolwent miał być fachowcem zdolnym do pracy wydawniczej i księgarskiej, o większym niż dotychczas bagażu wiedzy teoretycznej, zdolnym do prowadzenia własnej placówki.

Absolwent Kursów Księgarskich, swoją dotychczasową wiedzę fachową, zdobytą drogą terminowania w firmie księgarskiej, miał na Kursach ugruntować. Stwarzały mu one możliwość poznania podstaw teoretycznych wykonywanej pracy, historii księgarstwa, budowy książki, jej społecznej roli, zdobycia szerszej wiedzy o literaturze polskiej i obcej. Mówiąc wprost: powinien być dobrze przygotowanym do pracy handlowcem. Trzeba w tym miejscu dodać, że ten ostatni problem żywo interesował Muszkowskiego także z powodu rozporządzenia Prezydenta Rzeczypospolitej o prawie przemysłowym z 7 czerwca 1927 r., w myśl którego wszyscy praktykanci handlowi, w tym także praktykanci księgarscy, mieliby obowiązkowo uczęszczać do handlowej szkoły dokształcającej. W tej sytuacji - stwierdzał Muszkowski - uczeń spoza Warszawy uczęszczać będzie wyłącznie do takiej właśnie szkoły, bo innej nie ma; uczeń w stolicy musi do niej chodzić obowiązkowo, podczas, gdy do szkoły księgarskiej uczęszczać może, ale nie musi. W jego opinii wieczorowe uczęszczanie do szkoły handlowej odbiera uczniowi możliwość uczestnictwa w odbywających się, także wieczorem, wykładach w szkole księgarskiej. Muszkowski nie zarzucał szkołom handlowym niskiego poziomu, czy słabego przygotowania

${ }^{23}$ Więcej szczegółów zob.: Szkota zawodowa ksieggarska, tamże 1928, R. 14, nr 25, s. 389; nr 29, s. 623-624; 1931, R. 17, nr 19, s. 185. 
absolwentów. Wprost przeciwnie, doceniał wysiłki prowadzących je osób. Zaznaczał jednak, że „[...] księgarzowi potrzebne jest przygotowanie specjalne, że ekspedient, który znakomicie sprzedaje wyroby jubilerskie, towary bławatne lub kolonialne, postawiony za ladą księgarską, będzie zupełnie bezużyteczny" 24 . Księgarstwo - podkreślał - jest cząstką działalności handlowej, obejmującej wszelkie przedmioty - wytwory działalności ludzkiej. Nie działa w oderwaniu czy izolacji, jednak „Aby być dobrym księgarzem, trzeba być dobrym kupcem, a w tym celu trzeba poznawać i starać się zrozumieć istotę i warunki życia gospodarczego, trzeba uczyć się pilnie, teoretycznie i praktycznie, tej trudnej umiejętności, dotyczącej wytwarzania i wymiany wartości realnych [...]”25.

Znaczną trudnością było dla Muszkowskiego zapewnienie szkole księgarskiej odpowiedniego grona wykładowców, zwłaszcza księgarzy, którzy potrafiliby połączyć swoją wiedzę zawodową z umiejętnościami dydaktycznymi. Z kolei wykładowcy uniwersyteccy musieli pamiętać, aby zachować odpowiednie proporcje, specjalną - jak byśmy to określili - „perspektywę księgarską”, z punktu widzenia której będą spoglądali na historię literatury czy historię w ogóle. Przedmioty wykształcenia ogólnego powinny być bowiem tak opracowane, aby „wytyczyć potrzeby pracownika księgarskiego i dać mu odpowiedni zasób wiedzy, bez obciążania swych godzin balastem rozważań o charakterze teoretycznym, nadto odległym od praktyki codziennej"26. Ideałem, jak pisał Muszkowski, byłoby znalezienie wyjątkowego specjalisty: historyka literatury i jednocześnie księgarza. Ostatecznie do pracy w Studium udało się pozyskać m.in. Faustyna Czerwijowskiego (bibliotekarstwo), Gabriela Korbuta (historia literatury polskiej), Helenę Radlińską (technika pracy umysłowej, czytelnictwo), Natalię Gąsiorowską (historia powszechna i gospodarcza Europy Zachodniej); Jan Muszkowski prowadził zajęcia z bibliografii ogólnej i historii księgarstwa. $\mathrm{Na}$ Kursach wykłady prowadzili m.in. Regina Danysz-Fleszarowa (wiadomości o Polsce, ludności oraz o wytwórczości i handlu), Helena Radlińska (kultura współczesna i czytelnictwo), Juliusz Kaden-Bandrowski (literatura), Stanisław Jarkowski (prasa), Muszkowski (organizacja wytwarzania i obiegu książki), Adam Półtawski (drukarstwo), Jerzy Arct (sprzedaż w sortymencie), Hieronim Wilder (antykwariaty), Janina Mortkowiczowa (wydawnictwa artystyczne i dzieła sztuki w sortymencie), Bonawentura Lenart (estetyka książki), Jan Recmanik (introligatorstwo), Stanisław Arct (organizacja przedsiębiorstwa wydawniczego), Bogdan Suchodolski (polska literatura współczesna).

\footnotetext{
${ }^{24}$ J. Muszkowski, Nowe zadania. Tamże 1930, R. 16, nr 20, s. 271.

25 J. M., Szkota ksieggarska. Tamże, nr 4, s. 55.

26 Tenże, Szkota Ksieggarska powstaje! Tamże 1928, R. 14, nr 3, s. 37.
} 
Koszt kształcenia i utrzymania szkoły w nieznacznym stopniu obciążał słuchaczy. Koło Warszawskie ZKP w 1929 r. przeznaczyło na ten cel 1000 zł, w 1930 r. -1200 zł. Z ubolewaniem stwierdzano, że starania w Ministerstwie Przemysłu i Handlu oraz w Ministerstwie Wyznań Religijnych i Oświecenia Publicznego nie przyniosły żadnego rezultatu. Czesne w wysokości 60 zł rocznie opłacały za swoich pracowników firmy księgarskie ${ }^{27}$.

\section{Działalność szkoły księgarskiej w ocenie Muszkowskiego i środowiska księgarzy}

Pierwsze dwulecie szkoły zakończono 31 maja 1930 r. Jak podano w Sprawozdaniu z tego okresu, na Kursy Księgarskie zapisało się 37 osób: 32 mężczyzn i 5 kobiet w wieku 19-30 lat. Byli wśród nich księgarze-praktycy, graficy, papiernicy, introligator, księgowy, polonista, dziennikarz, literat, prawnik, historyk sztuki. Do egzaminów częściowych przystąpiło 3 słuchaczy Studium i 28 z Kursów ${ }^{28}$. W trakcie trwającej dwa lata nauki odbyto ogółem 310 godz. wykładów oraz 16 godz. ćwiczeń seminaryjnych, na których opracowano bibliografię „Przeglądu Księgarskiego” za lata 1910-1928. W zajęciach seminaryjnych uczestniczyli słuchacze Studium Księgarskiego oraz część słuchaczy Kursów Księgarskich. Zorganizowano trzy wspólne wycieczki do Domu Książki Polskiej, działu komisowo-hurtowego firmy Gebethner i Wolff oraz Towarzystwa Księgarń Kolejowych „Ruch”, co pozwoliło uczestnikom poznać strukturę organizacyjną tych instytucji. Programu nie udało się zrealizować $\mathrm{w}$ pełni z różnych przyczyn. $\mathrm{Z}$ powodu braku wykładowców nie odbył się zaplanowany wykład ze współczesnej literatury powszechnej, z organizacji przemysłu wydawniczego i księgarstwa sortymentowego za granicą i sortymentu zagranicznego w Polsce, pomocy szkolnych i materiałów piśmiennych oraz z wydawnictw artystycznych, map, atlasów i nut w sortymencie. Historia księgarstwa była wykładana w skromnym wymiarze 8 godz., gdyż „kierownik i wykładający w jednej osobie, prof. Muszkowski był przeciążony pracami organizacyjnymi" ${ }^{29}$. W Sprawozdaniu zaznaczono, że niektóre działy nauki o księgarstwie w ogóle nie były wykładane, inne powtórzono dwa razy, na każdym jednak roku nieco inaczej. $Z$ takich samych powodów zrezygnowano z pewnych przedmiotów pozaksięgarskich, lub ograniczono materiał z powodu zbyt małej liczby przewidzianych w programie godzin. Utrudnieniem dla wy-

\footnotetext{
27 Sprawozdanie Zarządu Gtównego Z.K.P. z dziatalności Związku w r. 1930. Tamże 1930, R. 16, nr 24, s. 327-328.

${ }_{28}$ Sprawozdanie z pierwszego dwulecia kursów księgarskich. Tamże, nr 12, s. 174-180.

${ }^{29}$ Tamże.
} 
kładających i studiujących był brak podręczników. Istniał, wydany w 1896 r. podręcznik Teodora Paprockiego Podręcznik księgarski. Przewodnik praktyczny dla wydawców, ksiegarzy, pomocników i praktykantów ksieggarskich na podstawie swojskich i obcych źródet opracowany, w którym autor, w dwóch częściach „Księgarnia nakładowa” i „Księgarnia sortymentowa” skupił się zwłaszcza na sprawach wydawniczych, wyglądzie książki i jej reklamie. Istniało też kilka poradników z lat dwudziestych oraz opracowania obcych autorów: Gastona Zelgera Manuel d'édition et de librairie (Paryż 1928) opisujący współczesne księgarstwo francuskie i jego metody, Maksa Paschkego i Philippa Ratha Lehrbuch des Deutschen Buchhandels (wyd. IV, Lipsk 1922) taktujące wyłącznie o księgarstwie niemieckim. Nie było jednak współcześnie wydanego podręcznika polskiego. Plan takiego podręcznika opublikował w 1931 r. Wojciech Gottlieb. Miał się on składać z dwóch części:

Część pierwsza: Książka

Rozdz. I. Bibliologia: 1. Zarys historii książki; 2. Szata zewnętrzna książki;

3. Stosunek człowieka do książki;

Rozdział II. Bibliografia; 1. Zasady bibliografii; 2. Praktyka bibliografii. Część druga: Księgarstwo

Rozdział I. Wydawnictwo: 1. Czynności redakcyjne; 2. Czynności związane z produkcją; 3. Kalkulacja i rachunkowość; 4. Czynności handlowe; 5. Propaganda

Rozdział II. Sortyment: 1. Urządzenie sortymentu; 2. Zakup książek; 3. Sprzedaż książek; 4. Propaganda; 5. Rachunkowość; 6. Działy specjalne;

7. Specjalne rodzaje księgarń

Rozdział III. Organizacje księgarskie [tu też: prasa fachowa; targi książki]: 1. Organizacje polskie; 2 . Organizacje zagraniczne ${ }^{30}$.

Poważnym problemem okazało się ustalenie poziomu wykładów, gdyż cenzus naukowy słuchaczy wahał się między dwoma biegunami: od pełnego kursu szkoły średniej (ok. 60\% uczestników Kursu Księgarskiego) do szkoły handlowej wieczorowej lub 5-7 klas szkoły powszechnej ${ }^{31}$. Przykładem konsekwencji takiego błędnego oszacowania wiedzy uczniów, był wykład z historii literatury przygotowany na wysokim poziomie, który dość szybko trzeba było zniżyć do poziomu elementarnych wiadomości z zakresu gramatyki i stylistyki. Podobne różnice obserwowano w latach odbytej praktyki zawodowej: od roku do 11 lat pracy. Jak stwierdzał Muszkowski, różnice

${ }^{30}$ Pełny plan podręcznika zob. W. Gottlieb, Plan polskiego podręcznika księgarskiego. Tamże 1931, R.17, nr 4, s. 37-39.

${ }^{31}$ [J. Muszkowski], Uczelnia księgarska $w$ ramach organizacji szkolnictwa zawodowego. Tamże, 1930, R.16, nr 15. s. 210-211. 
w poziomie wykształcenia przeszkadzały najbardziej w nauczaniu języków i rachunkowości.

Podsumowując pierwszy okres działania szkoły księgarskiej J. Muszkowski zastanawiał się nad zorganizowaniem w przyszłości Studium Księgarskiego z programem nauczania i poziomem skierowanym do absolwentów szkół wyższych, „szukających drogi do praktycznego wyzyskania swej wiedzy teoretycznej"32. Byłoby to zapewne możliwe, jednak pod warunkiem rzeczywistego zapotrzebowania na pracowników księgarskich posiadających przygotowanie naukowe. Autor konstatował, że obserwowany dyletantyzm w traktowaniu spraw wydawniczych i księgarskich potwierdza taką potrzebę, ale czy są takie możliwości? Czy absolwenci takiego studium znaleźliby potem zatrudnienie? Możliwości realizacyjnych należałoby szukać w połączeniu studiów księgarskich i bibliotekarskich istniejących w WWP. Natomiast z punktu widzenia Kursów Księgarskich, Muszkowski stwierdzał potrzebę dość radykalnych zmian, zarówno w programie, jak też w poziomie kursów. Stawiał pytanie, jak byśmy to dziś powiedzieli, o model absolwenta: „czy kształcimy przede wszystkim handlowców, czy też ludzi zaznajomionych z całym warsztatem kultury?"33. Wszelkie przeprowadzone zmiany programowe musiałyby być oczywistą konsekwencją odpowiedzi na to pytanie. Zdaniem Muszkowskiego, najlepszym rozwiązaniem byłoby najpierw wyszkolenie handlowca, a następnie jego wykształcenie humanistyczne.

Szkoła w dotychczasowym kształcie powinna, zdaniem Muszkowskiego, dać słuchaczom najcenniejszy owoc wszelkiego kształcenia: „przeświadczenie, że niewiele umieją" ${ }^{34}$, ponieważ takiego właśnie przeświadczenia brakuje w środowisku praktyków. Sami słuchacze wyrazili zainteresowanie dalszym kształceniem, w związku z czym powstał projekt założenia „Towarzystwa Przyjaciół Wiedzy Księgarskiej”.

Szkoła zyskała wysoką ocenę w oczach jej kuratora, Jana Piątka, co z pewnością można traktować jako głos ZKP i całego środowiska. Tak mówił na uroczystym zamknięciu pierwszego dwulecia Kursów: „Szkoła księgarska musi przede wszystkim spisać [...] wiedzę o księgarstwie, która dotąd tylko drogą tradycji była przekazywana z pokolenia na pokolenie. [...] musi zbadać wartość tej nauki dla dnia dzisiejszego i jutrzejszego. A wreszcie Szkoła Księgarska, opierając się na badaniu psychologicznym zarówno pracowników, jako też i klientów, i przyswajając sobie wyniki badań umysłowości społeczeństwa i jego potrzeb,

\footnotetext{
32 [J. Muszkowski], Szkota księgarska. Tamże, nr 4, s. 53.

33 Tamże, s. 54.

34 Tamże, s. 55.
} 
musi wytyczyć nowe drogi dla księgarstwa polskiego. W szkole tej musimy znaleźć nie tylko młodych współpracowników, dostatecznie przygotowanych do tej współpracy z nami - ale i odpowiednie wskazówki dla nas samych, tak by księgarstwo mogło spełniać w tych czasach swe zadanie dla dobra ogółu” ${ }^{35}$.

Z kolei prezes ZKP Gustaw K. Wolff, dziękując Janowi Muszkowskiemu za prowadzenie pierwszego Kursu stwierdzał, „że dokonany został wielki krok na drodze kształcenia młodego pokolenia, przy tym w sposób, napawający przeświadczeniem, że dalszy rozwój szkoły jest zapewniony"36. Niestety, Muszkowski świadom był braku zainteresowania losami szkoły ze strony czynników rządowych, które nie dość, że nie wspierały szkolenia zawodowego księgarzy finansowo, ale i moralnie nie widać było wsparcia z ich strony, gdyż Wydział Szkół Zawodowych MWR i OP nawet nie odpowiedział na zaproszenie do asystowania przy egzaminach końcowych. Wprawdzie organizacja księgarska czyniła wszystko, by sprostać kosztom utrzymania szkoły, ale kryzys ogólny i wzrastające wydatki groziły upadkiem placówki.

Trzeba uznać, że idea utworzenia szkolnictwa księgarskiego w Polsce, w okresie dwudziestolecia międzywojennego, nie zakończyła się sukcesem. W wyniku zmian organizacyjnych, w tym związanych z przeprowadzką WWP do nowych pomieszczeń, dalszym prowadzeniem kursów księgarskich zajmował się już samodzielnie Związek Księgarzy Polskich. Zorganizowano jeszcze dwa Kursy w latach 1932-1933 i 1934. Powołany został nowy Komitet szkolny, ale Jan Muszkowski pozostał kierownikiem Kursów do 1934 r., tzn. do końca ich trwania. Studium ukończył jeden student, Karol Haubold w 1933 r., a dyplom ukończenia Kursów wręczono 32 osobom $^{37}$. Muszkowski uczestniczył jeszcze w krótkoterminowych kursach szkolących różnych pracowników księgarń w 1938 i w 1939 r.

\section{Jana Muszkowskiego Projekt organizacji wewnętrznej stanu księgarskiego}

Mówiąc o roli Jana Muszkowskiego w kształtowaniu polskiego księgarstwa w okresie międzywojennym należy przypomnieć opublikowany w $1931 \mathrm{r}$. Projekt organizacji wewnętrznej stanu księgarskiego ${ }^{38}$ mający, w zamyśle autora, zintensyfikować prace nad konsolidacją zawodu księgarza. Mając już za sobą

35 Znaczenie szkoty zawodowej dla księgarstwa. Przemówienie D-ra J. Piątka na uroczystym zamknięciu pierwszego dwulecia Kursów Księgarskich. Tamże, nr 12, s. 174.

${ }_{36} Z$ życia organizacyjnego. Posiedzenie plenarne Zarządu Gtównego Z.K.P. w dn. 14.VI. 1930. Tamże, nr 13, s. 190 .

37 Klukowski, dz. cyt., s. 155.

38 J. Muszkowski, Projekt organizacji stanu księgarskiego. Tamże, 1931, R. 17, nr 2, s. 13-14. 
doświadczenia z okresu dwóch lat prowadzenia szkoły zawodowej, znajomość środowiska i świadomość kondycji książki w dobie kryzysu, swoje spostrzeżenia postanowił ująć w formie przepisów, które powinny zacząć jak najszybciej obowiązywać - konkretnie od 1 stycznia 1933 r. Stwierdzał, że w zawodzie księgarza obecni są praktykanci, pomocnicy księgarscy, kierownicy firm księgarskich. W przedstawionym projekcie Muszkowski definiował wszystkie pojęcia, przypisując konkretne zadania do poszczególnych grup. Praktykantem lub uczniem księgarskim określał osobę przyjętą na naukę przez zarejestrowaną firmę, która ma obowiązek dbać o zawodowy poziom praktykantów. Oni z kolei mają obowiązek uczęszczania do szkoły zawodowej dokształcającej, która powinna zastąpić im szkołę dokształcającą ogólną, przeznaczoną dla praktykantów handlowych. Z przeprowadzonych wcześniej obliczeń wynikało, że problem kształcenia i dokształcania mógł dotyczyć sporej grupy osób - w samej tylko Warszawie 56 praktykantów księgarskich uczęszczało do szkół dokształcających, przeznaczonych nie dla nich, a dla ekspedientów sklepowych ${ }^{39}$. Muszkowski zaznaczał, że w razie kłopotów z dotarciem do odpowiedniej szkoły, uczeń/praktykant powinien móc uczestniczyć w krótkotrwałych kursach korespondencyjnych organizowanych przez ZG ZKP. Po odbyciu praktyki i ukończeniu właściwej szkoły lub kursu, praktykant mógł zostać pomocnikiem księgarskim. Z kolei kierownikiem księgarni „[...] może zostać osoba, która ukończyła Studium Księgarskie przy Wydziale Pedagogicznym Wolnej Wszechnicy Polskiej w Warszawie, albo złożyła egzamin przed komisją, wyznaczoną przez Zarząd Główny Z.K.P w porozumieniu z Komitetem Studium Księgarskiego, oraz odbyła praktykę, uznaną za dostateczną przez Zarząd Główny Z.K.P”40. Osoby zajmujące stanowisko kierownika przed wejściem w życie przepisów (styczeń 1933 r.) byłyby zobligowane do ukończenia odpowiednich kursów.

We wnioskach Muszkowski podkreślał konieczność istnienia szkoły zawodowej dokształcającej dla praktykantów księgarskich w Warszawie oraz zbadanie możliwości założenia takich szkół w największych ośrodkach Rzeczypospolitej. Postulował opracowanie programu nauczania księgarstwa na stopniu podstawowym, średnim i wyższym; opracowanie programów i warunków egzaminów na pomocników księgarskich i kierowników księgarń; opracowanie programu i organizacji kursów dokształcających krótkotrwałych w Warszawie oraz kursów wyjazdowych, które mogłyby odbywać się na prowincji;

39 [J. Muszkowski], Obowiązkowa szkota doksztatcająca księgarska. Tamże, 1930, R. 16, nr 22, s. 293-294. Szczegółowe wyliczenia zob. też: B. Klukowski, dz. cyt., s. 61-63.

40 J. Muszkowski, Projekt organizacji stanu... 
podjęcie pracy zbiorowej nad przygotowaniem podręcznika księgarstwa, który ukazywałby się w formie częściowych opracowań na łamach „Przeglądu Księgarskiego" ${ }^{41}$.

\section{Podsumowanie}

Wszystkie prace podejmowane przez Jana Muszkowskiego w okresie międzywojennym, a związane z księgarstwem ${ }^{42}$, były wyrazem wielkiej troski o profesjonalne przygotowanie do pracy osób zajmujących się sprzedażą książek. W zawodzie księgarza dostrzegał z jednej strony znakomitych specjalistów, firmy o uznanej renomie, wielkie nazwiska, jak Arctów, Gebethnera i Wolffa, Adolfa Westa czy Jakuba Mortkowicza, a obok osoby przypadkowe, zupełnie do zawodu nieprzygotowane. Podkreślał, że w swojej ciężkiej, nieraz także fizycznej pracy, nie są odosobnieni, nie działają w izolacji - tak pracują księgarze na całym świecie. Stoją oni w jednym szeregu, obok bibliotekarzy różnych szczebli i innych pracowników instytucji kultury, których narzędziem pracy jest książka. Muszkowski starał się uświadomić młodzieży, ale też i całemu środowisku księgarskiemu i pracownikom ministerialnym, że podniesienie kwalifikacji ogólnych i fachowych jest niezbędne, by można dobrze, z misją uprawiać ten zwód. Potrzebne jest jednak do tego odpowiednie szkolnictwo zawodowe, które realizując stale udoskonalany program, stwarza możliwość poznania teoretycznych podstaw dyscypliny, jej historii, najnowszych światowych tendencji, ale także umiejętnej oceny rynku wydawniczego, reguł ekonomii, zasad reklamy książki (współczesny marketing księgarski), prawa, etyki zawodowej.

${ }^{41}$ W 1931 r. ukazał się pod redakcją J. Muszkowskiego pierwszy tom, pierwszego w Polsce wydawnictwa popularyzującego wśród księgarzy i miłośników książki wiedzę księgarską, pt. Biblioteka księgarska. Opublikowano w nim Projekt organizacji księgarstwa polskiego z czasów Królestwa Polskiego w opracowaniu i ze wstępem Tadeusza Sterzyńskiego. Sądzi się, że autorem projektu był Józef Zawadzki. Projekt ten był wcześniej publikowany w „Przeglądzie Księgarskim”.

${ }^{42}$ Poza przedstawionymi w artykule zagadnieniami należy pamiętać, że Muszkowski był w omawianym okresie (1930-1932) redaktorem „Przeglądu Księgarskiego”, którego poziom merytoryczny znacznie się polepszył, a „nasycenie” zagadnieniami księgarskimi było bardzo duże. Na jego łamach opublikowano wówczas szereg artykułów, które były istotną pomocą dydaktyczną dla słuchaczy Studium i Kursów. Muszkowski brał udział w wielu ważnych imprezach księgarsko-wydawniczych, opracował artykuły dotyczące J. Mortkowicza, E. Wende i Spółki, firmy M. Arcta oraz Gebethnera i Wolfa. Nie należy zapominać o udziale J. Muszkowskiego w pracach przedwojennej i powojennej Rady Książki. Szerzej o tych zagadnieniach: A. Kossuth, Jan Muszkowski jako księgarz. „Studia o Książce" 1973, t. 3, s. 171-178; M. Korczyńska-Derkacz, Dziatalność Rady Książki w Polsce (19451947). „Annales Universitatis Paedagogicae Cracoviensis (Studia ad Bibliothecarum Scientiam Pertinentia)" 2012, nr 10, s. 40-58. 


\section{Abstract \\ The role of Jan Muszkowski in the development of the Polish book trade in the inter-war period}

Jan Muszkowski, primarily known as a librarian, theoretician of book science and bibliographer, was also interested in bookselling: in its theory - with his research into book science - as well as in practical cooperation with booksellers. This article describes Jan Muszkowski's attempts to bestow on practical bookselling a fitting importance as well as to make it a subject for theoretical considerations. It presents the programme designed by Muszkowski for a newly founded school of professional booksellers. Thanks to its incorporation into Wolna Wszechnica Polska [Free Polish University] in Łódź, the school was to educate booksellers with two-year study courses (at tertiary level, addressed mainly to contemporary and future managers and owners of bookshops) as well as with courses of professional bookselling pitched at a lower level, addressed to bookselling apprentices. The article also presents opinions about these courses as held by contemporary booksellers as well as reflections of their organizer, Muszkowski himself.

In addition to the description of Muszkowski's role in organising education for professionals, the article presents Muszkowski's Projekt organizacji wewnętrznej stanu księgarskiego [The Project of the Book Trade Organisation], published in 1931, which was to intensify the consolidation of the bookselling profession. 